\title{
Inhalt.
}

\section{Zur Geschichte der Feststellungsklage.}

I. Das mittelalterliche deutsche Recht.

§ 1. Uebersicht . . . . . . . . . . . . . . . . . . . . . 2

§ 2. Klage und Feststellung. . . . . . . . . . . . . . . . 8

§ 3. Rechtsstreit unter Anspruchsprätendenten . . . . . . . 13

$\S 3^{\text {a }}$. Erbieten zur Vertheidigung. . . . . . . . . . . . . . 18

\$ 4. Freiwillige Gerichtsbarkeit und Feststellung . . . . . . 19

$\S 5$. Lehnrechtliche Anerkennungsklagen . . . . . . . . . . 24

\$6. Inquisitio und Feststellung . . . . . . . . . . . . . . 25

§ 7. Provokationsverfahren in Italien . . . . . . . . . . 27

II. Das mittelalterliche italienische Recht. - Das kanonische Recht. - Die italienische Doktrin.

§ 8. Klagen auf silentium imponi . . . . . . . . . . . . 33

$\S$ 9. Gerichtliche Confirmation. . . . . . . . . . . . . . . 39

$\S$ 10. Nichtigkeitsklage . . . . . . . . . . . . . . . . . . 42

$\S$ 11. Die Inquisitio in Feststellungsfunktion . . . . . . . . . 46

$\S$ 12. Das interdictum uti possidetis als Feststellungsmittel . . 50

§ 13. Klagvorwurf und Feststellung . . . . . . . . . . . . 54

§ 14. Incidente und principale Feststellungsklage. . . . . . . 55

$\S$ 15. Beurkundungsklage. (Urkundenanerkennung, Urkundenerneuerung.). . . . . . . . . . . . . . 58

§ 16. Publicatio testium . . . . . . . . . . . . . 67

§ 17. Provokationsverfahren im Statutarrecht . . . . . . . . 69

\$ 18. Provokationen des kanonischen Rechts. . . . . . . . . 75

§ 19. Rechtsstreit unter Anspruchsprätendenten . . . . . . . 76

$\S 20$. Die Extrajudicialappellation als Feststellungsmittel . . . 79

\$ 21. Das remedium ex l. diffamari. . . . . . . . . . . . . 88

$\S 22$. Das remedium ex l. si contendat. (Imploratio officii iudicis.)

- Die Schranke. . . . . . . . . . . . 90

§ 23. Actiones praeiudiciales . . . . . . . . . . . . . . . . 99

$\S$ 24. Anhang. Gemeinrechtliche Fortbildung . . . . . . . . 101 


\section{Die Feststellungsklage der Reichscivilprocess- ordnung.}

Seite

§ 1. Feststellung und Verurtheilung .. . . . . . . . . 113

$\S 2$. Der Inhalt des Feststellungsprocesses . . . . . . . . . 117

§ 3. Feststellung und Exekution . . . . . . . . . . . . . 119

§ 4. Die Wirkung des Feststellungsurtheils . . . . . . . . 121

$\S 5$. Vertheidigung des behaupteten Gegensatzes zwischen feststellendem und verurtheilendem Erkenntniss. . 124

§ 6. Grenzfälle . . . . . . . . . . . . . . . . . . . . . 136

$\$ 7$. Construktion der Feststellungsklage . . . . . . . . . 150

§ 8. Anticipation . . . . . . . . . . . . . . . . . . . . 155

§ 9. Rechtliches Interesse . . . . . . . . . . . . . 157

$\S$ 10. Weitere Consequenzen. . . . . . . . . . . . . . . . 162 